\title{
Reaksi transfer hidrogenasi minyak jarak kastor serta aplikasinya sebagai bahan pelunak kompon karet
}

\author{
Transfer hydrogenation of castrol oil and its \\ implementation as rubber plasticizer
}

\author{
Santi Puspitasari ${ }^{1, *}$, Adi Cifriadi ${ }^{1}$, Krisnawati $^{2}$, Tun Tedja Irawadi ${ }^{2}$ \\ 'Pusat Penelitian Karet, Jalan Salak Nomor 1 Bogor 16151, Indonesia \\ ${ }^{2}$ Departemen Kimia, Institut Pertanian Bogor, Kampus IPB Dramaga Bogor, Indonesia \\ *Penulis korespondensi : Telp.: +62-251-8319817; Fax.: +62-251-8324047 \\ E-mail: puspitasari.santi@puslitkaret.co.id
}

Diterima: 15 Juni 2016 Direvisi: 14 September 2016 Disetujui: 14 September 2016

\begin{abstract}
Rubber plasticizer is used to improve rubber processability so as to shorten time and reduce energy consumption during compounding. In general, rubber plasticizer is nonrenewable and environmentally harmful petroleum derivatives due to the carcinogenic property. Environmentally friendly plasticizer can be produced by transfer hydrogenation of vegetable oil. The research was aimed to synthesize new rubber plasticizer from transfer hydrogenation of castor oil using diimide compound which was generated in situ by oxidation of hydrazine hydrate and hydrogen peroxide as well as the application of the new rubber plasticizer obtained on natural and synthetic rubbers compounding. The result showed that the optimum condition of transfer hydrogenation was achieved at a capacity of $1000 \mathrm{ml}$ oil/batch, $40^{\circ} \mathrm{C}$ for 5 hours, and ratio hydrazine hydrate to hydrogen peroxide at 1:2 due to the hydrogenated castor oil (HCO) had the highest degree of hydrogenation and neutral pH. The application of 10 phr HCO had significant effect on the compounding of EPDM 6250 which was shown by shortest time and lowest energy of compounding, and also by the highest minimum torque modulus. In addition, the crosslink density of rubber vulcanizate which was formed during accelerated sulfur vulcanization was affected both by the addition of $\mathrm{HCO}$ and the saturation of the rubber being used.
\end{abstract}

Keywords: environmentally friendly plasticizer, castor oil, diimide hydrogenation, rubber.

\begin{abstract}
ABSTRAK
Bahan pelunak kompon karet berfungsi meningkatkan kemampuan proses karet sehingga dapat mempersingkat waktu dan menurunkan konsumsi energi selama pengomponan. Bahan pelunak karet yang umum digunakan berasal dari turunan minyak bumi yang tidak terbarukan dan tidak ramah lingkungan karena bersifat karsinogenik. Bahan pelunak kompon karet yang ramah lingkungan dapat diproduksi melalui reaksi transfer hidrogenasi minyak nabati. Penelitian ini bertujuan mempelajari sintesis bahan pelunak karet dari minyak jarak kastor secara transfer hidrogenasi menggunakan senyawa diimida yang dibangkitkan secara in situ oleh hidrasina hidrat dan hidrogen peroksida serta aplikasinya dalam pembuatan kompon karet alam (SIR 20) maupun sintetik (EPDM 6250, EPDM 6470, dan Butil 301). Hasil penelitian menunjukkan bahwa kondisi reaksi terbaik dicapai pada kapasitas reaksi sebesar $1000 \mathrm{ml}$ minyak/batch, suhu $40^{\circ} \mathrm{C}$ selama 5 jam dan rasio penambahan hidrasina hidrat terhadap hidrogen peroksida sebesar 1:2 karena menghasilkan derajat hidrogenasi tertinggi dan memiliki pH netral. Aplikasinya sebagai bahan pelunak alami sebesar 10 bsk berpengaruh signifikan terhadap proses pengomponan karet sintetik tipe EPDM 6250 karena saling memiliki kompatibilitas yang tinggi sehingga mampu memberikan waktu dan energi pengomponan serta nilai torsi minimum terendah. Derajat ikatan silang pada vulkanisat karet yang terbentuk saat vulkanisasi sulfur selain dipengaruhi oleh bahan pelunak juga oleh tingkat kejenuhan karet tersebut.
\end{abstract}

Kata kunci: bahan pelunak, hidrogenasi diimida, karet, minyak jarak kastor. 


\section{PENDAHULUAN}

Dalam pemilihan bahan kimia kompon karet perlu memperhatikan kualitas barang jadi karet yang dihasilkan, faktor kesehatan dan keselamatan kerja. Setiap jenis dan komposisi bahan kimia karet yang ditambahkan dalam karet mentah saat pembuatan kompon karet memiliki pengaruh spesifik terhadap proses manufaktur dan mutu produk karet terutama sifat mekanis serta umur pakainya. Jenis bahan kimia karet utama terdiri atas bahan pengisi, bahan antioksidasi, bahan pengaktif, bahan pencepat, bahan vulkanisasi dan bahan bantu olah (Ansarifar et al., 2007). Bahan bantu olah yang berfungsi untuk meningkatkan kemampuan pengolahan karet mencangkup golongan bahan pelunak yang bekerja secara fisik dan peptiser secara kimiawi (Karak, 2009).

Bahan pelunak yang ditambahkan pada komposisi 5-20 berat seratus karet (bsk) atau sekitar $10 \%$ terhadap bobot bahan pengisi dapat mengubah mekanisme pengomponan karet dan juga komponen di dalamnya (Chen et al., 2007). Bahan pelunak bekerja dengan cara menurunkan interaksi intermolekuler karet sehingga molekul karet menjadi lebih mudah bergerak dan mudah bercampur dengan bahan kimia karet akibatnya akan menurunkan energi dan waktu pengomponan. Kinerja bahan pelunak yang menentukan keefektifan plastisasi karet bergantung pada kompatibilitas antara bahan pelunak dan karet. Kompatibilitas tersebut dipengaruhi oleh polaritas dan tingkat difusi yang rendah dalam karet (Vieira et al., 2011) serta kesamaan daya kohesi karet dengan bahan pelunak. Bahan pelunak yang tidak kompatibel dengan karet akan menyebabkan kompon tidak homogen dan minyak akan berdifusi keluar menuju permukaan produk karet (Puspitasari \& Cifriadi, 2014a).

Bahan pelunak yang lazim digunakan dalam industri barang jadi karet berasal dari proses penyulingan minyak bumi (mineral oil) terdiri atas parafinik, naftenik dan aromatik (Cataldo et al., 2013). Minyak mineral aromatik sangat sesuai digunakan terutama untuk rubber based tyre seperti karet alam (NR), SBR, dan BR (Alexander \& Thachil, 2006). Namun bahan pelunak yang bersumber dari minyak mineral mempunyai beberapa kelemahan, antara lain tidak ramah lingkungan, iritan, korosif, dan karsinogenik karena mengandung senyawa polycyclic aromatic hydrocarbons (PAH) (Rahmaniar et al., 2009; Petchkaew, 2015). Selain itu, minyak bumi merupakan sumber daya alam yang tidak dapat diperbarui dan non-biode- gradable sehingga perlu alternatif sumber bahan pelunak lain yang bersifat dapat diperbarui, lebih ramah lingkungan dan aman bagi pekerja (Raju et al., 2007; Puspitasari \& Cifriadi, 2012; Wang et al., 2016). Minyak nabati seperti minyak kedelai, minyak kelapa, minyak biji karet dan minyak jarak kastor berpeluang digunakan dalam produksi bahan pelunak alami untuk kompon karet menggantikan minyak mineral sebagai bahan pelunak (Khalaf et al., 2015). Minyak nabati juga memenuhi peraturan European Directive 2005/69/EC yang sejak 2010 mempersyaratkan bahwa bahan pelunak harus mengandung PAH di bawah 10 ppm (Petchkaew, 2015).

Penggunaan minyak nabati sebagai bahan pelunak memerlukan modifikasi kimiawi terhadap struktur rantai molekul minyak nabati tersebut misalkan secara epoksidasi dan hidrogenasi sehingga dapat mengubah sifat fisiknya (Ariatmi et al., 2010; Samarth \& Mahanwar, 2015). Reaksi hidrogenasi akan memutus ikatan rangkap tak jenuh $\mathrm{C}=\mathrm{C}$ dalam molekul minyak nabati menjadi ikatan tunggal jenuh $\mathrm{C}-\mathrm{C}$ sehingga menyerupai rantai molekul pada minyak mineral parafinik. Reaksi hidrogenasi konvensional dengan gas $\mathrm{H}_{2}$ mempersyaratkan kondisi reaksi yang dijalankan pada suhu dan tekanan tinggi. Sedangkan reaksi transfer hidrogenasi yang menggunakan senyawa donor hidrogen seperti senyawa diimdia lebih sederhana karena dapat dilakukan pada suhu dan tekanan rendah sehingga meminimalkan biaya (Lin et al., 2004; Azhar et al., 2015). Senyawa diimida bersifat reaktif namun sangat tidak stabil sehingga hanya dapat digunakan secara in-situ dari hasil oksidasi hidrasina hidrat oleh hidrogen peroksida dalam reaksi transfer hidrogenasi katalitik maupun non katalitik (Smit et al., 2008; Kraft et al., 2011). Reaksi transfer hidrogensi senyawa tak jenuh dengan diimida sangat bergantung pada rasio komposisi hidrasina hidrat terhadap hidrogen peroksida, suhu dan waktu reaksi, katalis yang digunakan serta $\mathrm{pH}$ dalam sistem reaksi tersebut. Ion tembaga ( $\mathrm{Cu}$ (II) asetat, $\mathrm{Cu}$ (II) sulfat, dan $\mathrm{Cu}$ (II) perklorat) dianggap sebagai katalis yang sesuai untuk reaksi hidrogenasi (Lin et al., 2004). Menurut Lin et al. (2004), pada $\mathrm{pH}<8$, reaksi berjalan lambat, saat $\mathrm{pH}>8$ laju reaksi naik dengan cepat, dan pada $\mathrm{pH}=10$, mencapai maksimum.

Penelitian pembuatan minyak jarak kastor terhidrogenasi melalui reaksi transfer hidrogenasi oleh senyawa diimida pada kapasitas $300 \mathrm{ml} \mathrm{mi-}$ nyak/batch telah dilakukan oleh Puspitasari dan 
Cifriadi (2014b). Mereka menyatakan bahwa kondisi optimal diperoleh pada penambahan hidrasin hidrat $55 \%$ sebesar $2 \mathrm{M}$ dan hidrogen peroksida sebesar $0,6 \mathrm{M}$ pada suhu reaksi $40^{\circ} \mathrm{C}$ selama $7 \mathrm{jam}$. Pada penelitian Puspitasari dan Cifriadi (2014a) berikutnya minyak jarak kastor terhidrogenasi tersebut diuji cobakan dalam pembuatan kompon karet sintetik jenis EPDM 6250 dan mampu memberikan pengaruh penurunan waktu dan energi pengomponan yang cukup signifikan dibandingkan dengan minyak parafinik sintetik lain. Pengaruh minyak jarak kastor terhidrogenasi perlu dipelajari lebih lanjut terhadap proses pengomponan dan sifat mekanis dari berbagai jenis karet baik alam maupun sintetik terutama ethylene propylene diene monomer (EPDM) dan butyl (BR). Karet EPDM dan BR yang sangat kompatibel terhadap minyak parafinik banyak digunakan untuk memproduksi barang jadi karet dengan sifat ketahanan terhadap panas, cuaca, oksidasi dan pengusangan yang baik seperti selang karet, genteng karet, conveyor belt, serta barang karet mekanis lainnya sehingga kebutuhannya untuk industri barang jadi karet relatif cukup tinggi. Dengan demikian, hasil dari penelitian diharapkan dapat memberikan rekomendasi peluang pemanfatan minyak jarak kastor terhidrogenasi sebagai bahan pelunak karet alami dalam industri barang jadi karet.

Penelitian ini mempelajari reaksi transfer hidrogenasi minyak jarak kastor oleh senyawa diimida yang dibangkitkan secara in situ dari oksidasi hidrasina hidrat oleh hidrogen peroksida secara non katalitik pada berbagai suhu, waktu dan kapasitas reaksi. Selanjutnya minyak jarak kastor terhidrogenasi akan diujicobakan sebagai bahan pelunak karet alam pembuatan kompon karet alam (SIR 20) dan sintetik (EPDM dan BR).

\section{BAHAN DAN METODE \\ Bahan Penelitian}

Dalam pembuatan bahan pelunak alami secara transfer hidrogenasi digunakan minyak jarak kastor (Refined Bleached Deodorized, RBD Castor Oil) diperoleh dari PT. Kimia Farma, Semarang, Jawa Tengah, hidrasina hidrat $\left(\mathrm{N}_{2} \mathrm{H}_{4}\right.$, teknis kemurnian 80\%) dari Arc Chemical, Singapura dan hidrogen peroksida $\left(\mathrm{H}_{2} \mathrm{O}_{2}\right.$, teknis kemurnian 30\%) dari CV. Setia Guna, Bogor, Jawa Barat. Bahan kimia untuk karakterisasi bilang iod dan bilangan asam minyak meliputi pereaksi Hanus, kloroform $\left(\mathrm{CHCl}_{3}\right)$, natrium tiosulfat $\left(\mathrm{Na}_{2} \mathrm{~S}_{2} \mathrm{O}_{5}\right)$, kalium hidroksida $(\mathrm{KOH})$, indikator fenolftalein $(\mathrm{PP})$, indikator kanji $\left(\mathrm{C}_{6} \mathrm{H}_{10} \mathrm{O}_{5}\right)$, etanol $\left(\mathrm{C}_{2} \mathrm{H}_{6} \mathrm{O}\right)$, dan aseton $\left(\mathrm{C}_{3} \mathrm{H}_{6} \mathrm{O}\right)$ seluruhnya diperoleh dari Merck Jerman dengan spesifikasi pro analys (grade pa). Selanjutnya untuk pembuatan kompon karet digunakan karet alam SIR 20 dari PT. Perkebunan Nusantara VIII, Purwakarta, Jawa Barat dan karet sintetik jenis Ethylene Propylene Diene Monomer (EPDM 6250 dan EPDM 6470) serta Butyl 301 produksi Lanxess diperoleh dari distributor lokal PT. Multi Citra Chemindo Nusa, Jakarta. Bahan kimia karet yang terdiri atas bahan pengaktif seng oksida $(\mathrm{ZnO})$ dan asam stearat, bahan pengisi arang hitam (carbon black, CB N220) produksi Cabott, bahan antioksidasi trimetilkuinon (TMQ), bahan pencepat N-sikloheksil-2-benzotiazolasulfenamida (CBS), dan bahan pemvulkanisasi sulfur (S). Bahan kimia karet tersebut seluruhnya pada spesifikasi teknis diperoleh dari pemasok lokal CV. Indrasari, Bogor, Jawa Barat.

\section{Peralatan Penelitian}

Reaksi transfer hidrogenasi dijalankan dalam reaktor kaca labu leher tiga yang dilengkapi dengan termometer dan labu penetes hidrogen peroksida, hot plate magnetic stirrer merek Thermolyne Cimarec, penangas air sebagai media pemanas serta pengaduk magnetik. Laboratory glassware yang digunakan meliputi buret selbach, Erlenmeyer, beaker glass, gelas ukur, corong pemisah, corong kaca, dan cawan petri. Pembuatan kompon karet dilakukan dalam mesin giling terbuka (open mill) merek Berstorf. Instrumen analisis dan karakterisasi meliputi piknometer, viskometer Brookfield, $\mathrm{pH}$ meter, Fourier Transform Infrared (FTIR) spektrometer tipe Nicolet i5 dari Thermoscientific untuk uji gugus fungsi molekul dalam minyak jarak kastor terhidrogenasi, dan moving die rheometer (MDR 2000) dari Alpha Technologies untuk uji karakteristik vulkanisasi kompon karet.

\section{Metode Penelitian}

Reaksi transfer hidrogenasi minyak jarak kastor dengan senyawa diimida

Prosedur yang diterapkan pada reaksi transfer hidrogenasi dalam penelitian ini mengacu pada kegiatan sebelumnya (Puspitasari \& Cifriadi, 2014a; Puspitasari \& Cifriadi, 2014b). Sebanyak $500 \mathrm{ml}$ minyak jarak kastor dimasukkan ke dalam reaktor kemudian dipanaskan hingga mencapai suhu reaksi $\left(40,50\right.$, dan $\left.60^{\circ} \mathrm{C}\right)$. Ketika telah tercapai suhu reaksi yang dikehendaki, ke dalam minyak jarak kastor ditambah dengan hidrasina 
hidrat. Sedangkan hidrogen peroksida ditambahkan setetes demi setetes ( $5 \mathrm{ml} / \mathrm{menit})$. Rasio mol hidrasina hidrat terhadap hidrogen peroksida diatur sebesar 1:2 dan 2:1. Reaksi hidrogenasi dijalankan selama 1, 3, dan 5 jam. Waktu reaksi dihitung sejak tetes terakhir hidrogen peroksida. Minyak jarak kastor terhidrogenasi (HCO) yang diperoleh dimurnikan secara dekantasi menggunakan corong pemisah. HCO murni dikarakterisasi sifat kimia (gugus fungsi dengan spektroskopi FTIR, bilangan iod dan bilangan asam) serta sifat fisika (warna, densitas, viskositas, dan $\mathrm{pH}$ ).

Suhu dan waktu reaksi teroptimum pada reaksi hidrogenasi kapasitas $500 \mathrm{ml}$ minyak/batch selanjutnya diujicobakan dalam reaksi hidrogenasi pada kapasitas minyak jarak kastor sebesar 1000, 1500, dan $2000 \mathrm{ml}$ minyak per batch. HCO dengan karakteristik terbaik yang diperoleh dari tahap kedua ini kemudian diujicobakan sebagai bahan pelunak dalam pembuatan kompon karet alam maupun sintetik.

\section{Pembuatan Kompon Karet}

Karakterisasi kinerja HCO sebagai bahan pelunak alami dalam pembuatan kompon karet dibatasi hanya pada saat pengomponan dan karakterisasi vulkanisasi kompon karet. Pembuatan kompon karet mengikuti formulasi seperti disajikan pada Tabel 1. HCO ditambahkan pada dosis 10 bsk. Kompon kontrol sebagai pembanding dibuat tanpa penambahan bahan pelunak alami (HCO) menggunakan karet jenis SIR 20.

Tahapan dalam pembuatan kompon diawali dengan mastikasi karet hingga menjadi plastis dan lunak. Selanjutnya ke dalam karet yang telah plastis ditambah dengan bahan kimia karet sesuai dengan urutan bahan kimia pada Tabel 1. Setelah seluruh bahan kimia karet selesai ditambahkan, kompon karet terus digiling dalam open mill hingga menjadi homogen. Selama pembuatan kompon dilakukan pengamatan kinerja bahan pelunak terhadap waktu dan konsumsi energi pengomponan. Konsumsi energi diperhitungkan sebagai hasil perkalian antara daya mesin $(7,5 \mathrm{~kW})$ dengan waktu pengomponan. Kompon karet yang diperoleh didiamkan selama 20 jam pada suhu ruang agar dispersi bahan kimia karet semakin merata di dalam matriks karet. Kompon karet dicuplik sebanyak 50 gram untuk diuji karakteristik vulkanisasi pada $150^{\circ} \mathrm{C}$.

\section{Analisis dan Karakterisasi}

Analisis bilangan iod minyak jarak kastor yang mengikuti prosedur dalam Metode Hanus diperlukan sebagai dasar dalam perhitungan derajat hidrogenasi. Derajat hidrogenasi menggambarkan konversi dalam reaksi transfer hidrogenasi minyak jarak kastor oleh senyawa diimida. Rumus perhitungan bilangan iod, derajat hidrogenasi, dan bilangan asam disajikan dalam persamaan (1), (2), dan (3) sebagai berikut :

Bilangan iod $=\frac{[\mathrm{Vb}-\mathrm{Va}]}{\mathrm{m}} \times \mathrm{N} \times 12,60$

Derajat hidrogenasi $(\%)=\frac{[\mathrm{Co}-\mathrm{Ci}]}{\mathrm{Co}} \times 100 \%$

Bilangan asam $=\frac{\mathrm{Vsa}}{\mathrm{m}} \times \mathrm{Nsa} \times 56,1$

$\mathrm{Vb}$ adalah volume natrium tiosulfat untuk titrasi blangko, Vs adalah volume natrium tiosulfat untuk titrasi sampel, $\mathrm{N}$ adalah normalitas natrium tiosulfat $0,1 \mathrm{~N}$ (terstandarisasi), Co adalah bilangan iod minyak jarak kastor murni sebelum hidrogenasi, $\mathrm{Ci}$ adalah bilangan iod minyak jarak kastor setelah hidrogenasi, Vsa adalah volume KOH untuk titrasi

Tabel 1. Formula kompon karet.

\begin{tabular}{lcc}
\hline \multirow{2}{*}{ Karet dan bahan kimia karet } & \multicolumn{2}{c}{ Formula kompon (bsk) } \\
\cline { 2 - 3 } & Kontrol & Dengan HCO \\
\hline Karet (SIR 20, EPDM 6250, EPDM 6470, Butil 301) & 100 & 100 \\
ZnO & 5 & 5 \\
Asam Stearat & 2,5 & 2,5 \\
Bahan pelunak : HCO & 0 & 10 \\
CB 220 & 45 & 45 \\
TMQ & 1,5 & 1,5 \\
CBS & 0,8 & 0,8 \\
Sulfur & 2,5 & 2,5 \\
\hline
\end{tabular}


sampel, dan Nsa adalah normalitas $\mathrm{KOH}$.

Analisis kualitatif minyak jarak kastor dilakukan menggunakan spektroskopi FTIR pada rentang bilangan gelombang 4000-400 $\mathrm{cm}^{-1}$. Pengamatan difokuskan pada serapan bilangan gelombang sekitar $3008 \mathrm{~cm}^{-1}$ untuk gugus fungsi ikatan rangkap $\mathrm{C}=\mathrm{C}$. Pada $\mathrm{HCO}$ juga dilakukan pengujian berat jenis dengan piknometer, kekentalan dengan viskometer Brookfield (spindle no 2) dan $\mathrm{pH}$.

\section{HASIL DAN PEMBAHASAN}

Reaksi transfer hidrogenasi senyawa tak jenuh oleh diimida berlangsung melalui mekanisme secara reduksi karena terjadi pemutusan ikatan rangkap $\mathrm{C}=\mathrm{C}$ dalam rantai molekul trigliserida atau asam lemak tak jenuh penyusun minyak jarak kastor oleh atom $\mathrm{H}$ yang berasal dari senyawa diimida membentuk ikatan jenuh HC$\mathrm{CH}$. Berdasarkan hasil penelitian Mahittikul, et al. (2007) dapat diketahui bahwa reaksi transfer hidrogenasi berlangsung dalam dua tahap sebagai berikut :

1. Pembentukan senyawa diimida dari oksidasi hidrasina hidrat oleh hidrogen peroksida

$$
\mathrm{NH}_{2} \mathrm{NH}_{2}+\mathrm{H}_{2} \mathrm{O}_{2} \rightarrow \mathrm{NH}=\mathrm{NH}+2 \mathrm{H}_{2} \mathrm{O}
$$

2. Pemutusan ikatan rangkap $\mathrm{C}=\mathrm{C}$ trigliserida oleh diimida menjadi ikatan tunggal

$$
\mathrm{NH}=\mathrm{NH}+\mathrm{CH}_{2}=\mathrm{CH}_{2} \rightarrow \mathrm{N}_{2}+\mathrm{CH}_{3}-\mathrm{CH}_{3}
$$

Lin (2005) menyatakan reaksi samping yang mungkin terjadi selama berjalannya reaksi trans- fer hidrogenasi antara lain:

1. Pembentukan nitrogen oleh hidrasina hidrat dan hidrogen peroksida

$$
\mathrm{NH}_{2} \mathrm{NH}_{2}+2 \mathrm{H}_{2} \mathrm{O}_{2} \rightarrow \mathrm{N}_{2}+4 \mathrm{H}_{2} \mathrm{O}
$$

2. Dekomposisi hidrasina hidrat menjadi amoniak dan nitrogen

$$
3 \mathrm{~N}_{2} \mathrm{H}_{4} \rightarrow 4 \mathrm{NH}_{3}+\mathrm{N}_{2}
$$

3. Dekomposisi hidrogen peroksida menjadi oksigen dan air

$$
2 \mathrm{H}_{2} \mathrm{O}_{2} \rightarrow \mathrm{O}_{2}+2 \mathrm{H}_{2} \mathrm{O}
$$

Berlangsungnya reaksi transfer hidrogenasi ditandai oleh beberapa fenomena seperti kenaikan suhu reaksi, timbul gas dan buih serta perubahan warna dan fase pada minyak jarak kastor (Puspitasari \& Cifriadi, 2012). Perubahan suhu yang mengiringi reaksi transfer hidrogenasi disajikan dalam kurva pada Gambar 1. Berdasarkan Gambar 1 terlihat bahwa kecenderungan perubahan suhu terhadap waktu reaksi lebih dipengaruhi oleh rasio komposisi antara hidrasina hidrat dengan hidrogen peroksida. Sedangkan pada variasi suhu reaksi menghasilkan pola perubahan suhu yang sama. Perbandingan konsentrasi pereaksi menentukan efektivitas reaksi. Secara kualitatif, efektivitas reaksi ditandai dengan kenaikan suhu reaksi yang signifikan karena reaksi hidrogenasi berjalan secara eksotermis.

Hidrogen peroksida lebih berpengaruh terhadap reaksi transfer hidrogenasi. Jumlah hidrogen peroksida berlebih akan terus bereaksi dengan hidrasina hidrat meskipun setelah tetes terakhir

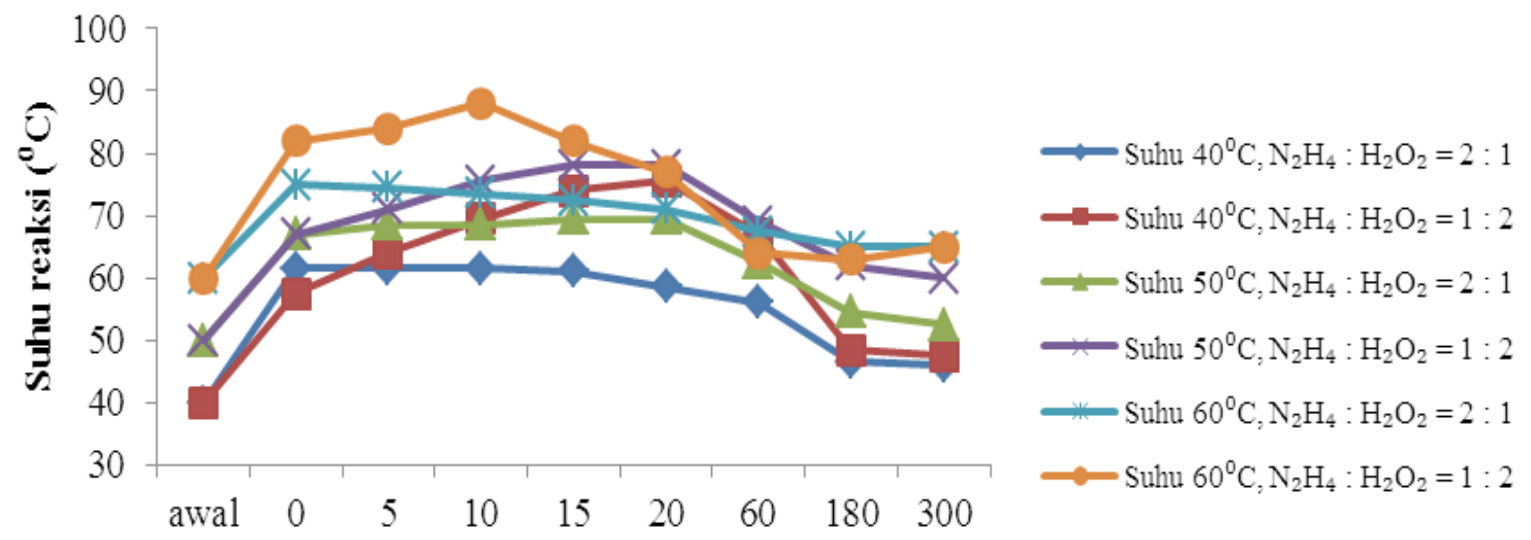

\section{Reaksi menit ke-}

Gambar 1. Perubahan suhu reaksi transfer hidrogenasi minyak jarak kastor oleh senyawa diimida pada kapasitas reaksi sebesar $500 \mathrm{ml}$ minyak/batch. Titik awal hingga reaksi menit ke-0 adalah durasi pada saat penambahan tetesan hidrogen peroksida ke dalam campuran minyak jarak kastor dan hidrasina hidrat. Reaksi menit ke-0 mulai diperhitungkan setelah seluruh hidrogen peroksida habis ditambahkan (tetes terakhir). 
penambahan hidrogen peroksida dalam campuran minyak jarak kastor dan hidrasina hidrat sehingga memberikan dampak eksotermis yang signifikan yang berarti bahwa reaksi pemutusan ikatan rangkap $\mathrm{C}=\mathrm{C}$ berlangsung lebih optimal. Gejala lain yang mengindikasikan terjadinya reaksi transfer hidrogenasi adalah terbentuknya gas dan buih serta perubahan warna minyak jarak kastor seperti ditampilkan pada Gambar 2.

Analisis secara kualitatif pembentukan ikatan tunggal dalam minyak jarak kastor terhidrogenasi (HCO) turut dibuktikan dengan hasil spektroskopi FTIR (Gambar 3). Pada spektra minyak jarak kastor terlihat adanya puncak serapan pada bilangan gelombang sekitar $3008 \mathrm{~cm}^{-1}, 1240 \mathrm{~cm}^{-1}$, dan $723 \mathrm{~cm}^{-1}$ milik ikatan rangkap $\mathrm{C}=\mathrm{C}$ dalam rantai molekul trigliserida (Marin et al., 2012). Intensitas puncak serapan ini sedikit berkurang pada spektra FTIR HCO akibat terkonversinya ikatan $\mathrm{C}=\mathrm{C}$ menjadi $\mathrm{C}-\mathrm{C}$ (Gambar 4). Puncak serapan tajam terlihat pada bilangan gelombang $1740 \mathrm{~cm}^{-1}$ milik ikatan $\mathrm{C}=\mathrm{O}$ gugus ester pada rantai molekul asam lemak risinoleat. Minyak jarak kastor mengandung asam lemak risinoleat sebesar $87 \%$, kadar gugus $\mathrm{C}=\mathrm{O}$ tidak berubah dalam minyak jarak kastor setelah reaksi transfer hidrogenasi karena tidak diadisi oleh atom $\mathrm{H}$ dari diimida (Yousef et al., 2001). Selain itu tampak adanya pelebaran intensitas serapan pada bilangan gelombang sekitar $3390 \mathrm{~cm}^{-1}$ milik gugus $-\mathrm{OH}$ yang berasal dari rantai asam lemak risinoleat dan molekul $\mathrm{H}_{2} \mathrm{O}$ produk samping reaksi transfer hidrogenasi.

Bilangan iod dan derajat hidrogenasi merupakan tolok ukur utama kesempurnaan reaksi hidrogenasi minyak jarak kastor. Bilangan iod menggambarkan tingkat ketidakjenuhan minyak nabati sedangkan derajat hidrogenasi dianggap mewakili konversi reaksi transfer hidrogenasi minyak jarak kastor. Minyak jarak kastor yang telah mengalami reaksi hidrogenasi memiliki bilangan iod lebih

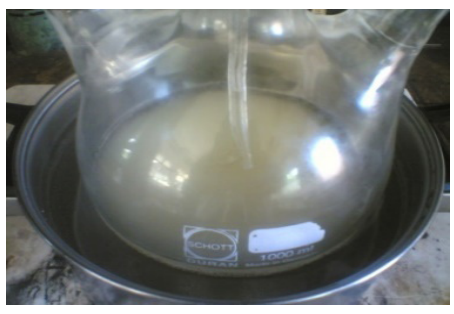

A

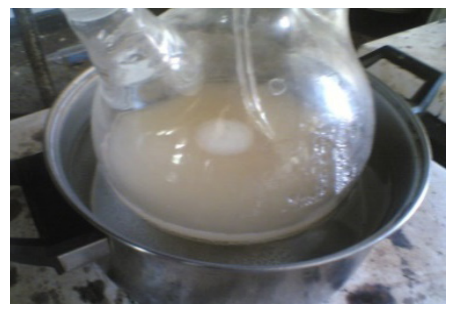

B

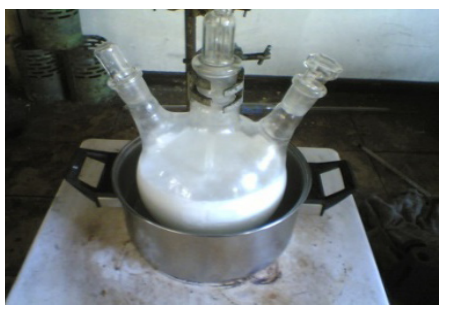

C

Gambar 2. Indikator reaksi transfer hidrogenasi minyak jarak kastor, (A) minyak jarak kastor sebelum reaksi-berwarna kuning, (B) awal penetesan hidrogen peroksida-berwarna jingga, (C) akhir penetesan hidrogen peroksida-berwarna putih.

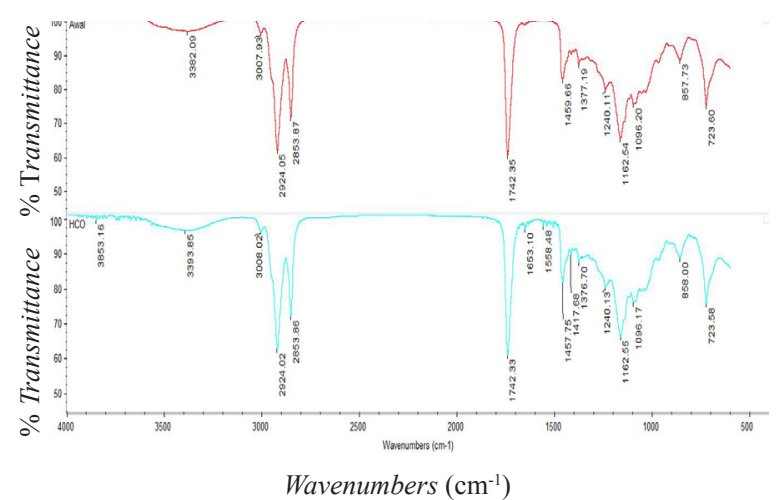

Gambar 3. Spektra FTIR minyak jarak kastor (merah-atas) dan HCO (biru-bawah). Kapasitas reaksi $500 \mathrm{ml}$ minyak/batch, suhu reaksi $40^{\circ} \mathrm{C}$ dan rasio hidrasina hidrat dan hidrogen peroksida sebesar 1:2.

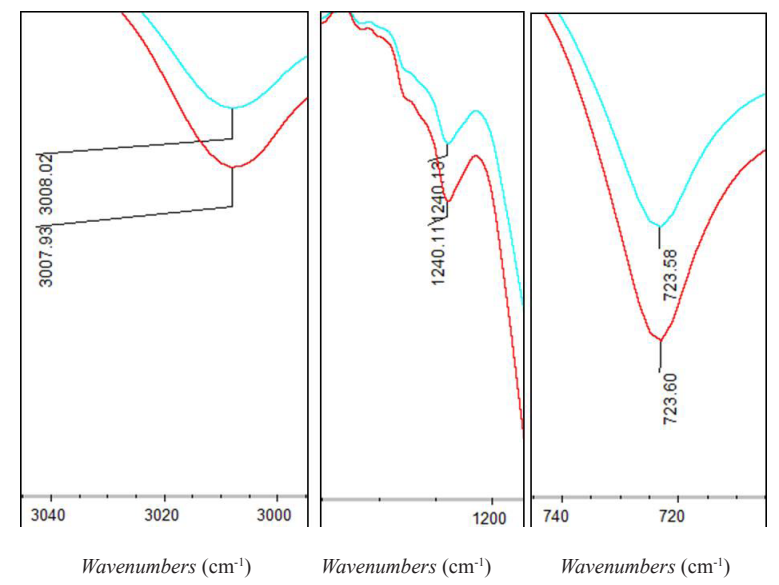

Gambar 4. Pergeseran pada puncak serapan ikatan $\mathrm{C}=\mathrm{C}$. Minyak jarak kastor (merah-bawah) dan HCO (biru-atas). 
Tabel 2. Sifat kimia minyak jarak kastor terhidrogenasi (kapasitas $500 \mathrm{ml}$ minyak/batch).

\begin{tabular}{|c|c|c|c|c|c|c|c|c|c|}
\hline \multirow{2}{*}{$\begin{array}{l}\text { Jam } \\
\text { ke- }\end{array}$} & \multicolumn{3}{|c|}{$\begin{array}{c}\text { Bilangan iod } \\
\text { (g/100 g minyak) }\end{array}$} & \multicolumn{3}{|c|}{$\begin{array}{c}\text { Derajat hidrogenasi } \\
(\%)\end{array}$} & \multicolumn{3}{|c|}{$\begin{array}{c}\text { Bilangan asam } \\
\text { (g KOH/g minyak) }\end{array}$} \\
\hline & $40^{\circ} \mathrm{C}$ & $50^{\circ} \mathrm{C}$ & $60^{\circ} \mathrm{C}$ & $40^{\circ} \mathrm{C}$ & $50^{\circ} \mathrm{C}$ & $60^{\circ} \mathrm{C}$ & $40^{\circ} \mathrm{C}$ & $50^{\circ} \mathrm{C}$ & $60^{\circ} \mathrm{C}$ \\
\hline \multicolumn{10}{|c|}{ Rasio $\mathrm{NH}_{2} \mathrm{NH}_{2} \cdot \mathrm{H}_{2} \mathrm{O}: \mathrm{H}_{2} \mathrm{O}_{2}=1: 2$} \\
\hline 1 & 86,41 & 85,03 & 88,40 & 9,42 & 10,87 & 7,34 & 1,20 & 1,12 & 1,12 \\
\hline 3 & 69,69 & 82,02 & 84,02 & 26,95 & 14,02 & 11,93 & 1,44 & 1,28 & 1,16 \\
\hline 5 & 60,87 & 75,84 & 78,09 & 36,19 & 20,50 & 18,15 & 1,68 & 1,60 & 1,36 \\
\hline \multicolumn{10}{|c|}{ Rasio $\mathrm{NH}_{2} \mathrm{NH}_{2} \cdot \mathrm{H}_{2} \mathrm{O}: \mathrm{H}_{2} \mathrm{O}_{2}=2: 1$} \\
\hline 1 & 82,34 & 83,44 & 86,62 & 13,69 & 12,53 & 9,20 & 1,28 & 1,09 & 1,17 \\
\hline 3 & 73,37 & 78,56 & 80,14 & 23,09 & 17,63 & 16,00 & 1,44 & 1,21 & 1,32 \\
\hline 5 & 70,04 & 77,06 & 77,70 & 26,58 & 19,22 & 18,55 & 1,52 & 1,36 & 1,44 \\
\hline
\end{tabular}

rendah dibandingkan dengan minyak jarak kastor awal, namun derajat hidrogenasi yang lebih tinggi akibat teradisinya ikatan rangkap $\mathrm{C}=\mathrm{C}$ dalam trigliserida minyak jarak kastor oleh atom $\mathrm{H}$ dari senyawa diimida. Pengujian bilangan asam diperlukan untuk mengetahui kandungan asam lemak bebas dalam minyak jarak kastor. Hasil karakterisasi sifat kimia minyak jarak kastor awal diperoleh bilangan iod sebesar $95,39 \mathrm{~g}$ iod/100 $\mathrm{g}$ minyak dan bilangan asam sebesar 1,62 $\mathrm{g} \mathrm{KOH} / \mathrm{g}$ minyak dan sifat kimia HCO dirangkum pada Tabel 2.

Penurunan bilangan iod terbesar diperoleh pada suhu $40^{\circ} \mathrm{C}$, waktu reaksi 5 jam dan rasio hidarsina hidrat terhadap hidrogen peroksida sebesar 1:2 yaitu $60,87 \mathrm{~g}$ iodin/100 g minyak, sehingga menghasilkan derajat hidrogenasi tertinggi sebesar $36,19 \%$. Pada suhu $40^{\circ} \mathrm{C}$, dekomposisi hidrogen peroksida membentuk radikal hidroksil dapat diminimalisasi sehingga jumlah hidrogen peroksida yang bereaksi dengan hidrasina hidrat menghasilkan senyawa diimida menjadi optimal. Sedangkan pada suhu lebih tinggi, kemungkinan dekomposisi hidrogen peroksida membentuk radikal hidroksil menjadi lebih besar. Hasil pengujian bilangan asam pada kisaran 1,12-1,68.

Sifat fisika HCO yang dirinci dalam Tabel 3 turut menentukan kesempurnaan reaksi transfer hidrogenasi minyak jarak kastor. Nilai viskositas berhubungan erat dengan bilangan iod, semakin tinggi penurunan bilangan iod maka minyak akan

Tabel 3. Sifat fisika minyak jarak kastor terhidrogenasi (kapasitas $500 \mathrm{ml}$ minyak/batch), waktu reaksi $=5 \mathrm{jam}$.

\begin{tabular}{|c|c|c|c|c|c|}
\hline \multicolumn{2}{|c|}{ Rasio Pereaksi, mol } & \multicolumn{4}{|c|}{ Sifat minyak jarak kastor terhidrogenasi } \\
\hline $\mathrm{N}_{2} \mathrm{H}_{4}$ & $\mathrm{H}_{2} \mathrm{O}_{2}$ & Warna & Densitas, $\mathrm{g} / \mathrm{ml}$ & $\begin{array}{c}\text { Viskositas, } \\
\mathrm{Cp}\end{array}$ & $\mathrm{pH}$ \\
\hline \multicolumn{6}{|c|}{ Suhu reaksi $=40^{\circ} \mathrm{C}$} \\
\hline 1 & 2 & Kuning & 0,9616 & 461,25 & 5 \\
\hline 2 & 1 & Kuning & 0,9624 & 466,25 & 5 \\
\hline \multicolumn{6}{|c|}{ Suhu reaksi $=50^{\circ} \mathrm{C}$} \\
\hline 1 & 2 & Kuning & 0,9578 & 464,38 & 5 \\
\hline 2 & 1 & Jingga & 0,9583 & 470,00 & 5 \\
\hline \multicolumn{6}{|c|}{ Suhu reaksi $=60^{\circ} \mathrm{C}$} \\
\hline 1 & 2 & Jingga & 0,9607 & 462,50 & 5 \\
\hline 2 & 1 & Jingga & 0,9587 & 468,75 & 5 \\
\hline
\end{tabular}


Tabel 4. Sifat kimia HCO hasil kapasitas reaksi 1000 - $2000 \mathrm{ml}$ minyak/batch.

\begin{tabular}{cccccccccc}
\hline \multirow{2}{*}{ Rasio } & \multicolumn{8}{c}{ Kapasitas reaksi (ml minyak/batch) } \\
\cline { 2 - 10 } $\mathrm{N}_{2} \mathrm{H}_{4}:$ & 1000 & 1500 & 2000 & 1000 & 1500 & 2000 & 1000 & 1500 & 2000 \\
\cline { 2 - 10 } $\mathrm{H}_{2} \mathrm{O}_{2}$ & \multicolumn{3}{c}{ Bilangan iod } & \multicolumn{7}{c}{ Derajat hidrogenasi } & \multicolumn{3}{c}{ Bilangan asam } \\
\hline $1: 2$ & 58,79 & 51,97 & 75,86 & 38,37 & 54,52 & 20,47 & 1,28 & 1,99 & 1,43 \\
$2: 1$ & 38,90 & 74,45 & 82,72 & 59,22 & 21,95 & 13,28 & 1,28 & 1,44 & 1,44 \\
\hline
\end{tabular}

makin kental (Rao \& Prasad, 2004). Bahkan pada derajat hidrogenasi yang sangat tinggi, minyak dapat berubah menjadi padat. Viskositas HCO diperoleh sebesar 461-470 cP. Kondisi tersebut akan meningkatkan kerapatan massa sehingga densitas HCO mengalami peningkatan (berkisar 0,9578$0,9624 \mathrm{~g} / \mathrm{ml})$. Berdasarkan nilai $\mathrm{pH}$ diketahui bahwa $\mathrm{HCO}$ bersifat sedikit asam $(\mathrm{pH}=5)$. Warna minyak jarak terhidrogensi dipengaruhi oleh rasio pereaksi. Warna minyak yang gelap dihasilkan dari konsentrasi hidrasina hidrat lebih besar dibandingkan hidrogen peroksida.

Mengacu pada hasil karakterisasai $\mathrm{HCO}$ yang diperoleh dari reaksi transfer hidrogenasi minyak jarak kastor kapasitas $500 \mathrm{ml}$ minyak/batch pada berbagai suhu maka dapat ditetapkan bahwa suhu dan waktu optimum reaksi sebesar $40^{\circ} \mathrm{C}$ dan 5 jam. Kondisi ini mampu menghasilkan $\mathrm{HCO}$ yang memiliki spesifikasi terbaik pada setiap rasio pereaksi dan akan diujicobakan dalam reaksi transfer hidrogenasi pada kapasitas minyak jarak kastor sebesar 1000, 1500, dan $2000 \mathrm{ml}$ minyak/ batch. Peningkatan kapasitas reaksi dimaksudkan untuk mengkaji kelayakan produksi dan komersialisasi bahan pelunak alami karet secara transfer hidrogenasi minyak jarak kastor.

Tabel 4 merangkum sifat kimia HCO yang disintesis pada kapasitas reaksi di atas $500 \mathrm{ml} /$ batch. Bilangan iod HCO terendah $(38,90)$ diikuti dengan derajat hidrogenasi terbesar $(59,22 \%)$ tercapai pada kapasitas reaksi sebesar $1000 \mathrm{ml}$ minyak/batch dengan rasio mol hidrasin hidrat terhadap hidrogen peroksida sebesar 2:1. Pengujian bilangan asam menunjukkan angka pada kisaran 1,11-1,99. Faktor tumbukan antar partikel pereaksi dalam reaksi transfer hidrogenasi berperan penting dalam pembentukan konversi atau derajat hidrogenasi reaksi yang tinggi. Pada kecepatan pengadukan yang ditetapkan konstan untuk seluruh kapasitas reaksi (1000-2000 ml minyak/ batch) maka pada kapasitas reaksi sebesar 1000 $\mathrm{ml}$ minyak/batch akan mengalami tumbukan partikel pereaksi yang terbesar, akibatnya reaksi transfer hidrogenasi menjadi paling optimal. Apabila dibandingkan dengan derajat hidrogenasi pada kapasitas $500 \mathrm{ml}$ minyak/batch, pada kapasitas $1000 \mathrm{ml}$ minyak/batch menghasilkan derajat hidrogenasi yang lebih besar juga akibat pengaruh kecepatan pengadukan yang diatur lebih tinggi pada kapasitas $1000 \mathrm{ml}$ minyak/batch dibandingkan pada $500 \mathrm{ml}$ minyak/batch.

Karakterisasi sifat fisika $\mathrm{HCO}$ hasil reaksi kapasitas 1000-2000 ml minyak/batch ditampilkan dalam Tabel 5. HCO berwarna antara kuning

Tabel 5. Sifat fisika HCO hasil kapasitas reaksi 1000 - $2000 \mathrm{ml}$ minyak/batch.

\begin{tabular}{ccccccc}
\hline $\begin{array}{c}\text { Kapasitas } \\
\text { minyak, } \\
(\mathrm{ml} / \text { batch })\end{array}$ & \multicolumn{2}{c}{ Rasio pereaksi, mol } & Warna & $\begin{array}{c}\text { Densitas, } \\
(\mathrm{g} / \mathrm{ml})\end{array}$ & $\begin{array}{c}\text { Viskositas, } \\
(\mathrm{C})\end{array}$ & $\mathrm{pH}$ \\
\hline \multirow{2}{*}{1000} & 1 & 2 & Kuning & 0,9633 & 475 & 5,33 \\
& 2 & 1 & Jingga & 0,9586 & 488 & 7,09 \\
\multirow{2}{*}{1500} & 1 & 2 & Kuning & 0,9615 & 475 & 5,05 \\
& 2 & 1 & Jingga & 0,9571 & 500 & 8,16 \\
2000 & 1 & 2 & Jingga & 0,9563 & 475 & 5,63 \\
& 2 & 1 & Jingga & 0,9584 & 418 & 8,07 \\
\hline
\end{tabular}


keruh hingga jingga. Perbedaan warna diakibatkan karena adanya perbedaan ukuran partikel di antara sampel HCO yang dibiaskan oleh cahaya. Ukuran partikel yang kecil memberikan efek warna yang lebih terang (Liu, 2009). Pada komposisi hidrogen peroksida yang lebih besar dari hidrasin hidrat memberikan efek warna yang lebih terang. Dalam konsentrasi dan suhu reaksi yang tinggi, peluang hidrogen peroksida membentuk radikal hidroksil menjadi besar. Radikal hidroksil ini menyebabkan reaksi samping yaitu dekomposisi asam lemak membentuk asam lemak yang memiliki panjang rantai dan bobot molekul lebih rendah sehingga ukuran partikel asam lemak dalam HCO cenderung menjadi kecil.

Nilai $\mathrm{pH}$ HCO juga ditentukan oleh rasio pereaksi. Komposisi hidrasina hidrat yang lebih tinggi menyebabkan sifat basa pada HCO. Hal ini disebabkan karena hidrasina hidrat bersifat basa kuat dengan nilai $\mathrm{pH} 10$. Sedangkan pada parameter densitas dan viskositas nilai relatif konstan dengan adanya pemutusan ikatan rangkap $\mathrm{C}=\mathrm{C}$ ketika dihidrogenasi.

Berdasarkan hasil karakterisasi HCO seperti disajikan dalam Tabel 4 dan 5 maka dalam implementasinya sebagai bahan pelunak alami kompon karet dipilih menggunakan minyak jarak kastor yang direaksikan pada kapasitas $1000 \mathrm{ml}$ minyak/ batch dengan rasio penambahan hidrasin hidrat dan hidrogen peroksida sebesar 2:1, dengan pertimbangan bahwa HCO tersebut memiliki derajat hidrogenasi tertinggi dan $\mathrm{pH}$ netral.

Pengaruh bahan pelunak alami HCO dalam pembuatan kompon karet diamati melalui parameter waktu dan konsumsi energi pengomponan, seperti ditampilkan dalam Gambar 5. Kompon

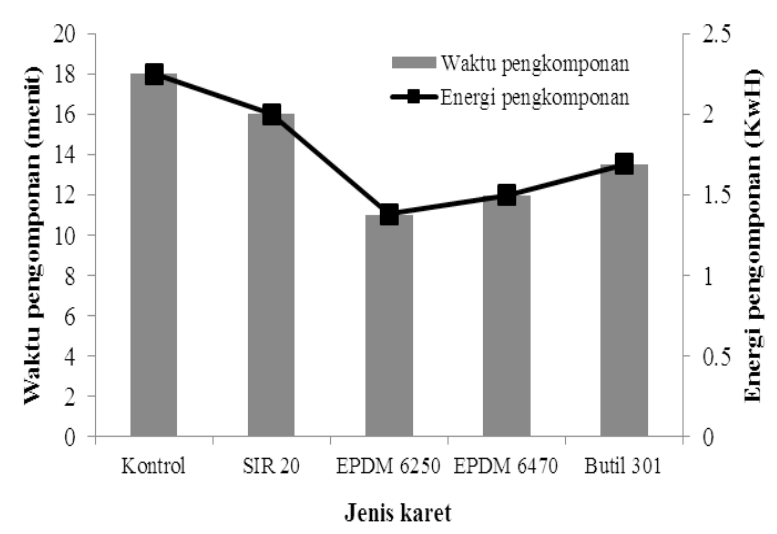

Gambar 5. Parameter pengomponan karet dengan penambahan HCO. kontrol (tanpa penambahan HCO) memerlukan waktu pengomponan terlama sehingga mengkonsumsi energi pengomponan terbesar yang diikuti oleh kompon karet alam SIR 20, karet sintetik EPDM 6250, EPDM 6470, dan Butil 301. Adanya efek pelumasan $\mathrm{HCO}$ menyebabkan rantai molekul polimer karet menjadi mudah bergerak (Arayapranee \& Rempel, 2007). Efek ini mengakibatkan padatan bahan kimia karet saat ditambahkan ke dalam matriks karet menjadi lebih mudah bercampur membentuk kompon yang homogen. Efek pelumasan oleh HCO pada molekul karet semakin terasa apabila antara $\mathrm{HCO}$ dan karet memiliki kompatibilitas yang tinggi, ditunjukkan oleh kesamaan tingkat polaritas. HCO termasuk dalam golongan senyawa non polar meskipun memiliki gugus polar (ikatan $\mathrm{OH}$ ) dalam susunan trigliseridanya sehingga sesuai untuk karet sintetik jenis EPDM dan Butil, namun kurang sesuai untuk jenis karet alam (NR, SIR 20). Karet alam yang bersifat sedikit lebih polar daripada EPDM dan Butil cocok menggunakan bahan pelunak jenis minyak aromatik dan alkil monoester (Chandrasekaran, 2010; Mckeen, 2012).

Parameter pengomponan juga dipengaruhi oleh sifat dasar karet yang digunakan terutama viskositas Mooney karet yang menggambarkan bobot molekul karet tersebut. Karet yang memiliki viskositas Mooney rendah cenderung bersifat lunak, sehingga mempercepat tahapan mastikasi dan pencampuran bahan kimia terutama bahan pengisi pada saat pengomponan. Selain itu, juga menyebabkan molekul HCO lebih mudah melakukan penetrasi atau menyisip diantara rantai molekul karet sehingga memberikan efek pelumasan yang besar. Karet alam memiliki viskositas Mooney sebesar 57-64 M, karet EPDM 6250 dan 6470 sebesar 55 dan $57 \mathrm{M}$ sedangkan karet butil 301 sebesar 56 M (Lanxess, 2007).

Kemampuan proses karet alam juga dapat diketahui dari hasil pengujian karakteristik vulkanisasi kompon karet (Khalaf et al., 2015). Mengacu pada hasil pengujian karekteristik vulkanisasi pada suhu $150^{\circ} \mathrm{C}$ (Tabel 6), kompon SIR 20 memiliki waktu vulkanisasi optimum (opt time) yang tercepat yaitu 9,49 menit, diikuti oleh kompon kontrol, EPDM 6470, EPDM 6250, dan Butil 301. Sedangkan untuk parameter waktu pra vulkanisasi (scorch time) secara berurutan adalah kontrol, SIR 20, EPDM 6470, dan EPDM 6250. Nilai torsi minimum (Smin) pada karet sintetik cenderung lebih besar daripada karet alam. Nilai 
sebaliknya terlihat pada parameter torsi maksimum (Smaks). Demikian pula dengan parameter pembentukan ikatan silang. Derajat ikatan silang yang dianalogkan dengan nilai delta torsi (selisih antara torsi maksimum dengan torsi minimum) pada karet sintetik cenderung lebih rendah dibandingkan karet alam (Oh et al., 2014). Derajat ikatan silang tertinggi dihasilkan oleh kompon kontrol 14,07 kg-cm dan terendah kompon karet Butil 301 sebesar $2 \mathrm{~kg}-\mathrm{cm}$.

Nilai torsi minimum yang besar dan torsi maksimum yang rendah mengindikasikan meningkatnya kemampuan proses karet akibat pengaruh penambahan bahan pelunak HCO (Formela et al., 2015; Khalaf et al., 2015; Wang et al., 2016). HCO dapat menurunkan viskositas karet serta mempermudah pergerakan rantai molekul karet sehingga meningkatkan kemampuan pemrosesan karet tersebut. Pengaruh HCO semakin terlihat pada karet sintetik dibandingkan dengan karet alam, karena antara HCO dan karet sintetik (EPDM maupun BR) saling memiliki kompatibilitas yang tinggi. Nilai kompatibilitas tersebut selain ditentukan berdasarkan polaritas juga oleh nilai parameter kelarutan (solubility parameters) yang saling berdekatan (Wang et al., 2016). Parameter kelarutan untuk minyak jarak kastor, karet alam, karet EPDM dan karet BR secara berurut-turut sebesar $18,3 \mathrm{MPa}^{1 / 2} ; 16,5 \mathrm{MPa}^{1 / 2} ; 18,1 \mathrm{MPa}^{1 / 2} ; 18,1 \mathrm{MPa}^{1 / 2}$ (Cataldo et al., 2013; Wang et al., 2016).

Derajat ikatan silang dalam vulkanisat karet dipengaruhi oleh kandungan tak jenuh (ikatan $\mathrm{C}=\mathrm{C}$ ) dalam rantai molekul karet, jenis dan dosis bahan pencepat, bahan pengaktif dan bahan pemvulkanisasi. Pada penelitian ini, dosis dan jenis bahan pencepat, bahan pengaktif, dan pemvulkanisasi ditetapkan sama untuk seluruh kondisi sistem vulkanisasi sulfur sehingga yang paling menentukan besarnya derajat ikatan silang hanya kandungan ikatan $\mathrm{C}=\mathrm{C}$ dalam setiap karet (Gonzales et al., 2005). Mekanisme sistem vulkanisasi sulfur terjadi dengan pemutusan ikatan rangkap $\mathrm{C}=\mathrm{C}$ pada rantai molekul karet yang digantikan oleh molekul lain yang selanjutnya saling membentuk jaringan tiga dimensi (Restrepo-Zapata et al., 2014).

Pada karet tak jenuh (unsaturated rubber) seperti karet alam, sistem vulkanisasi sulfur sangat berpengaruh terhadap pembentukan ikatan silang (Iqbal et al., 2008). Sedangkan dengan menerapkan sistem vulkanisasi sulfur pada karet sintetik jenuh (saturated synthetic rubber) seperti EPDM dan Butil yang hanya memiliki sedikit kandungan $\mathrm{C}=\mathrm{C}$, hanya mampu menghasilkan derajat ikatan silang yang rendah (Zhao et al., 2001). Untuk karet EPDM dan Butil lebih sesuai digunakan sistem vulkanisasi peroksida (Zhao et al., 2001; Chandrasekaran, 2010). Sistem vulkanisasi peroksida berjalan dengan mekanisme pembentukan radikal bebas oleh senyawa peroksida. Radikal bebas tersebut selanjutnya menyerang rantai molekul karet sehingga terbentuk makroradikal molekul karet. Tahap berikutnya antar makroradikal molekul karet yang berdekatan akan saling bereaksi menghasilkan ikatan silang antar atom $\mathrm{C}$ dari kedua rantai molekul karet tersebut. Untuk jenis karet yang sama yaitu EPDM, derajat ikatan silang EPDM 6250 lebih rendah daripada EPDM 6470. Dalam EPDM 6250 mengandung ethylidene norbornene (ENB) dan gugus etilen sebesar 2,2 dan $62 \%$ sedangkan pada EPDM 6470 sebesar 4,5 dan $68 \%$ (Lanxess, 2007). Kandungan ENB (diena) dalam struktur molekul EPDM yang memiliki ikatan rangkap $\mathrm{C}=\mathrm{C}$ merupakan gugus aktif untuk vulkanisasi sulfur.

Waktu vulkanisasi optimum dipengaruhi oleh dosis penambahan bahan pengisi dan bahan pencepat, pembentukan ikatan silang oleh sufur

Tabel 6. Karakterisasi vulkanisasi kompon karet.

\begin{tabular}{lccccc}
\hline \multirow{2}{*}{ Kompon karet } & \multicolumn{5}{c}{ Parameter karakteristik pemasakan kompon } \\
\cline { 2 - 6 } & $\begin{array}{c}\text { Torsi }(\mathrm{S}) \\
\text { Maks } \\
(\mathrm{Kg}-\mathrm{cm})\end{array}$ & $\begin{array}{c}\text { Torsi }(\mathrm{S}) \\
\text { Min } \\
(\mathrm{Kg}-\mathrm{cm})\end{array}$ & $\begin{array}{c}\Delta \text { Torsi } \\
(\Delta \mathrm{S}) \\
(\mathrm{Kg}-\mathrm{cm})\end{array}$ & $\begin{array}{c}\text { Opt Time } \\
(\mathrm{t} 90) \\
(\text { Menit })\end{array}$ & $\begin{array}{c}\text { Scorch Time } \\
(\mathrm{ts} 2) \\
(\text { Menit })\end{array}$ \\
\hline Kontrol & 15,59 & 1,52 & 14,07 & 10,16 & 2,07 \\
SIR 20 & 10,06 & 1,04 & 9,02 & 9,49 & 2,40 \\
EPDM 6250 & 9,21 & 2,37 & 6,84 & 24,11 & 6,01 \\
EPDM 6470 & 10,3 & 1,89 & 8,41 & 23,58 & 5,31 \\
Butil 301 & 3,84 & 1,84 & 2 & 26,10 & N/A \\
\hline
\end{tabular}


dan kestabilan panas dari ikatan sulfur tersebut (Aprem et al., 2003; Khimi \& Pickering, 2014). Pembentukan ikatan silang selama vulkanisasi berkaitan dengan kemampuan rantai molekul karet untuk bergerak. Semakin fleksibel rantai molekul karet maka semakin sulit terbentuk ikatan silang yang mengakibatkan reaksi vulkanisasi memerlukan waktu yang panjang, seperti terlihat pada waktu vulkanisasi optimum karet EPDM dan Butil (Khimi \& Pickering, 2014). Kompon karet Butil tidak terjadi pravulkanisasi. Kompon karet butil memerlukan bahan pencepat tipe ultra fast supaya dapat terjadi reaksi vulkanisasi yang ideal (Martin et al., 1962). Sedangkan dalam penelitian hanya digunakan bahan pencepat CBS yang termasuk dalam golongan sulfenamida merupakan bahan pencepat tipe fast delayed action (Rodgers, 2015).

\section{KESIMPULAN}

Kondisi optimum reaksi transfer hidrogenasi minyak jarak kastor oleh senyawa diimida berkapasitas $1000 \mathrm{ml}$ minyak/batch tercapai pada suhu $40^{\circ} \mathrm{C}$ selama 5 jam dengan rasio komposisi hidrasina hidrat terhadap hidrogen peroksida sebesar 2:1 karena mampu menghasilkan derajat hidrogenasi tertinggi yaitu sebesar 59,22\%. Pada dosis 10 bsk, pengaruh minyak jarak kastor tersebut sebagai bahan pelunak alami dalam pembuatan kompon karet cukup signifikan terutama terhadap parameter pengomponan (waktu dan konsumsi energi) khususnya untuk karet EPDM dan Butil karena saling memiliki kompatibilitas yang tinggi.

\section{UCAPAN TERIMA KASIH}

Ucapan terima kasih disampaikan kepada Pusat Penelitian Karet atas dukungan pendanaan melalui Program Riset In House Tahun Anggaran 2013 sehingga kegiatan penelitian ini dapat terlaksana dengan baik.

\section{DAFTAR PUSTAKA}

Alexander, M., \& Thachil, E. T. (2006). A comparative study of cardanol and aromatic oil as plasticizers for carbon-black-filled natural rubber. Journal of Applied Polymer Science, 102, 4835-4841, http://dx.doi.org/10.1002/app.24811

Ansarifar, A., Critchlow, G. W., Guo, R., Ellis, R. J., Kirtley, S. P., \& Seymour, B. (2007). Effect of rubber chemicals on the surface free energy of NR and NR-SBR rubber blends. Journal Rubber Research, 10(3), 148-160.

Aprem, A. S., Joseph, K., Mathew, T., Altstaedt, V., \&
Thomas, S. (2003). Studies on accelerated sulphur vulcanization of natural rubber using 1-phenyl-2, 4-dithiobiuret/tertiary butyl benzothiazole sulphenamide. European Polymer Journal, 39, 1451-1460, http://dx.doi.org/10.1016/S0014$\underline{3057(02) 00382-8}$

Arayapranee, W., \& Rempel, G. L. (2007). Effects of cashew nut shell liquid as a plasticizer on cure characteristic, processability and mechanical properties of 50:50 NR/EPDM blends: A comparison with paraffin oil. Journal of Applied Polymer Science, 106, 1696-2702, http://dx.doi. org/10.1002/app.25936

Ariatmi, N. R., Djumali, M., Ani, S., Machfud, M., \& Sudradjat, S. (2010). Optimasi proses dan kinetika reaksi epoksidasi minyak jarak pagar (Jatropa curcas L.) dengan hidrogen peroksida. Jurnal Teknologi Industri Pertanian, 18(2), 66-70.

Azhar, N. H. A., Jamaluddin, N., Rasid, H. M., Yusof, M. J. M., \& Yusoff, S. F. M. (2015). Studies on hydrogenation of liquid natural rubber using diimide. International Journal of Polymer Science, 12, 1-6, http://dx.doi.org/10.1155/2015/243038

Cataldo, F., Ursini, O., \& Angelini, G. (2013). Biodiesel as a plasticizer of a SBR-based tire tread formulation. ISRN Polymer Science, 1-9, http://dx.doi.org/10.1155/2013/340426

Chandrasekaran, V. C. (2010). Rubber as a construction materialfor corrosion protection: a comprehensive guide for process equipment. Canada: Scrivener Publishing LLC.

Chen L., Gong, X. L., Jiang, W. Q., Yao, J. J., Deng, H. X., \& Li, W. H. (2007). Investigation on magnetorheological elastomers based on natural rubber. Journal of Materials Science., 42(14), 5483-5489, $\quad$ http://dx.doi.org/10.1007/s10853006-0975-x

Formela, K., Wasowicz, D., Formela, M., Hejna, A., \& Haponiuk, J. (2015). Curing characteristics, mechanical and thermal properties of reclaimed ground tire rubber cured with various vulcanizing systems. Iran Polymer Journal, 24, 289-297, http://dx.doi.org/10.1007/s13726-015-0320-9

Gonzales, H. L., Rodriguez, D. A., Valetin, J. L., Marcos-Fernandez, A., \& Posadas, P. (2005). Conventional and efficient crosslinking of natural rubber effect of heterogeneities on the physical properties. Elastomer and Plastics, 58(12), 638643.

Iqbal, M., Akhter, T., Farooqui, Z., \& Mahmood, K. (2008). The effects of plasticizer and filler on the curing characteristic and mechanical properties of (SBR) styrene butadiene rubber and (CR) chloroprene rubber blends. Journal Chemical Society of Pakistan, 30(4), 507-511.

Karak, N. (2009). Fundamentals of polymers material to finish products. New Delhi, India: Learning 
Private Limited.

Khalaf,A. I., Ward, A. A., El-Kader, A. E, \& El-Sabbagh, S. H. (2015). Effect of selected vegetable oils on the properties of acrylonitrile-butadiene rubber vulcanizates. Polimery, 60(1), 43-56, http:// dx.doi.org/10.14314/polimery.2015.043

Khimi, S. R., \& Pickering, K. L. (2014). A new method to predict optimum cure time of rubber compound using dynamic mechanical analysis. Journal of Applied Polymer Science, 131(6), 1-6, http:// dx.doi.org/10.1002/app.40008

Kraft, V., Kretzschmar, G.,\& Rossen, K. (2011). Process for the production of atermisinin intermediate, US Patent 0230669 A1 tanggal publikasi 22 September 2011, United States.

Lanxess. (2007). Buna EP ethylene propylene rubber the versatile elastomer. Germany: Lanxess.

Lin, X., Pan, Q., \& Rempel, G.L. (2004). Cupric ion catalyzed diimide production from the reaction between hydrazine and hidrogen peroxide, Journal of Applied. Catalysis A : General, 263(1), 27-32, Http://dx.doi.org/10.1016/j.apcata.2003.11.035

Lin, X. (2005). Hydrogenation of unsaturated polymers in latex form (Thesis), University of Waterloo, Ontario, Canada.

Liu, K. S. (2009). Effects of particle size distribution, compositional and color properties of ground corn on quality of distillers dried grains with solubles (DDGS). Bioresource Technology, 100(19), 4433-4440. http://dx.doi.org/10.1016/j. biortech.2009.02.067

Mahittikul, A., Prasassarakich, P., \& Rempel, G. L. (2007). Diimide hydrogenation of natural rubber latex. Journal of Applied Polymer Science, 105(3), 1188-1199, http://dx.doi.org/10.1002/app.25944

Marin, M. J. G., Garcia, F. P., \& Santillan, Y. M. (2012). Obtaining and characterization of biodiesel from castor oil (ricinus communis) and sunflower (helianthus annuus) grown in Tabasco, Mexico. International Journal of Applied Science and Technology, 2(9), 58-74.

Martin, J. G., Ernst, J. L., Jankowski, C. J., \& Scheteliclr, A. A. (1962). US Patent No. 3023195 $A$, Washington, USA: U.S. Patent and Trademark Office.

McKeen, L. W. (2012). Film properties of plastics and elastomers. (3rd ed.). USA: Elsevier Inc.

Oh, J., Yoo, Y. H., Yoo, I. S., Huh, Y.I., Chaki, T. K., \& Nah, C (2014). Effect of plasticizer and curing system on freezing resistance of rubbers. Journal of Applied Polymer Science, 131, 1-8, http:// dx.doi.org/10.1002/app.39795

Petchkaew, A. (2015). Implication of non carcinogenic PAH-extender oils in natural rubber based tire compounds (Thesis), University of Twente and Prince of Songkla University, Netherland and Thailand.
Puspitasari, S., \& Cifriadi, A. (2012). Kajian pembuatan bahan pelunak karet berbasis hayati dari minyak jarak melalui reaksi hidrogenasi. Warta Perkaretan, 31(1), 50-56.

Puspitasari, S., \& Cifriadi, A. (2014a). Karakterisasi minyak jarak terhidrogenasi sebagai bahan pelunak karet alami. Jurnal Penelitian Karet, $32(1), 65-73$.

Puspitasari, S., \& Cifriadi, A. (2014b). Pembuatan bahan pelunak alami untuk kompon karet melalui reaksi hidrogenasi minyak jarak castor. Jurnal Penelitian Karet, 32(1), 56-64.

Rahmaniar, R., Gatot, P., \& Basuni, H. (2009). Pembuatan kompon karet dengan penambahan minyak kemiri (candlenut oil) epoksi. Dinamika Penelitian BIPA, 20(35), 59-68.

Rao, R. R., \& Prasad, K. R. (2004). Effects of velocity slip and viscosity variation on journal bearings. The ANZIAM Journal, 46(1), 143-155, http:// dx.doi.org/10.1017/S1446181100013730

Raju, P., Nandanan, V., \& Kutty Sunil, K. N. (2007). A study on the use of coconut oil as plasticiser in natural rubber compounds. Journal Rubber Research, 10(1), 1-16.

Restrepo-Zapata, N. C., Osswald, T. A., \& HernandezOrtiz, J. P. (2014). Vulcanization of EPDM rubber compounds with and without blowing agents: Identification of reaction events and TTTdiagram using DSC data. Polymer Engineering and Science, 55(9), 2073-2088, http://dx.doi. org/10.1002/pen.24049

Rodgers, B. (2015). Rubber compounding: chemistry and applications, second edition. Florida, USA: CRC Press.

Samarth, N. B., \& Mahanwar, P. A. (2015). Modified vegetable oil based additives as future polymeric material - review. Open Journal of Organic Polymer Materials, 5, 1-22, http://dx.doi. org/10.4236/ojopm.2015.51001

Smit, C., Fraaije, M. W., \& Minnaard, A. J. (2008). Reduction of carbon-carbon double bonds using organocatalytically generated diimide. Journal of Organic Chemistry, 73(23), 9482-9485, http:// dx.doi.org/10.1021/jo801588d

Vieira M. G. A., da Silva, M. A., dos Santos, L.O., \& Beppu, M.M. (2011). Natural-based plasticizers and biopolymer films: A review. European Polymer Journal, 47(13), 254-263, http://dx.doi. org/10.1016/j.eurpolymj.2010.12.011

Wang, Z., Peng, Y., Zhang, L., Zhao, Y., Vyzhimov, R., Tan, T., \& Fong, H. (2016). Investigation of palm oil as green plasticizer on the processing and mechanical properties of ethylene propylene diene monomer rubber. Industrial \& Engineering Chemistry Research, 55(10), 2784-2789, http:// dx.doi.org/10.1021/acs.iecr.5b04527

Yousef, E. A. A., Hussain, A. E., \& Shoeb, Z. E. (2001). 
Modification of castor oil by isomerization, halogenation and application of some modified product as plasticizer in nitril rubber formulation. Journal of Scientific and Industrial Research, 60, 383-395.
Zhao, J., Ghebremeskel, G., \& Peasely, J. (2001). Properties of EPDM/SBR blends cured with peroxide and sulfur coagent. Elastomer and Plastics, 54, 223-228. 
